\title{
THE PROBLEM OF TRANSITION IN KANT'S OPUS POSTUMUM
}

\author{
İsmail SERIN ${ }^{*+}$
}

\begin{abstract}
In this paper, I try to reveal the nature of the transition problem in Kant's Opus Postumum. Scientific developments in eighteenth century, particularly the ones in chemistry, forces philosophers to re-evaluate the role of scientific findings in the philosophical debates. In addition to these crucial developments, we observe that the a prioricity for Kant primarily depends on the physical nature of the matter which implies moving forces, but the developments in chemistry add a new dimension to the problem. Once again, Kant, after the publication of the third Critique, starts to think about the possibility of a transition from The Metaphysical Foundation of Natural Science to physics. If we succeed to construct a proper transition, we not only save the sciences from being just aggregation of the empirical data, but we may fill the gap between the knowledge about the matter and the nature as a whole.
\end{abstract}

Keywords: Science, critique, transition, Opus Postumum.

\section{KANT'IN OPUS POSTUMUM ADLI YAPITINDA GEÇİŞ SORUNU}

Öz: Bu makalede Kant'ın Opus Postumum adlı yapıtında ele alınan geçiş sorununun doğasını ortaya koymaya çalışacağım. On sekizinci yüzyıldaki bilimsel gelişmeler, özellikle kimya alanındakiler, filozofları felsefe tartışmaları yürütürken bilimsel bulgularını rolünü yeniden değerlendirmeye zorlar. Bu önemli değişikliklerin yanı sıra Kant'ın önsellik anlayışının büyük ölçüde hareket eden güçleri ima eden fiziksel maddeye yaslandığını gözlemliyoruz. Kant bir kez daha üçüncü Eleştiri'nin basımından sonra, Doğa Biliminin Metafizik Temelleri'nden fiziğe geçiş olanağı üzerinde düşünmeye başlar. Eğer düzgün bir geçiş kurmayı başarırsak, bilimleri yalnızca deneysel veriler yığını olmaktan kurtarmakla kalmayacak, ayrıca maddeye dair bilgimiz ile bütün olarak doğa arasındaki boşluğu da doldurmuş olacağız.

Anahtar Kelimeler: Bilim, eleştiri, geçiş, Opus Postumum.

\footnotetext{
* Dr. Öğr. Üyesi I Asst. Prof.

Ondokuz Mayıs Üniversitesi, Fen-Edebiyat Fakültesi, Felsefe Bölümü, Türkiye I Ondokuz Mayıs University, Faculty of Arts and Sciences, Department of Philosophy, Turkey

e-mail: ismail.serin@omu.edu.tr

Orcid Id: 0000-0002-3164-5181
}

Serin, İ. (2019). The Problem of Transition in Kant's Opus Postumum. Kilikya Felsefe Dergisi, (2), 32-41.

${ }^{\dagger}$ The ideas and discussions in this paper depend largely on the conclusions of my graduate theses. 


\section{Philosophical Background of the Problem}

Kant's early thoughts about the nature of space and time are under the influence of Leibniz and Newton. But, without further ado, he found both positions unsatisfactory. In Inaugural Dissertation (1929/1979) Kant developed views on space and time which shares the same theoretical framework of his Critique of Pure Reason (1965). According to this approach, without space and time all human knowledge remains baseless and as a result of this destruction, nothing remains firm.

Knowing subjects build up their concepts of space and time throughout a regulative process of the mind in which everything always obeys the laws of nature. Human minds produce the senses of the physical objects after this regulative process of the mind. As a result of Kant's analysis, as we think space and time as the main components of answering the question "How do we know in general?", the role of mind expresses a critical shift about the nature of human knowledge. Epistemology in Kant's hands becomes the main subject of the modern philosophy.

Our mind regulates its senses according to unchanging laws so that we gain the concepts of space and time. The presence of the physical objects or objects in general produce the senses in the mind. This relation implies a change in understanding the nature of the space and time. Now, space and time become epistemological entities rather than ontological terms. Kant makes a distinction between relative space and absolute space at the beginning of "Phoronomy" in The Metaphysical Foundations of Natural Science (1786). Since the relative space is nothing but the sum total of objects of experience, Newtonian absolute space becomes something full of these relative spaces. So, Kant refuses to recognize an ontological importance the notion absolute space. From this viewpoint, Kant defends the physical bodies with determinate material limits that is with definite shape. Matter, according to Kant of Dissertation, is the element of sensible world on the hand, and the element of intelligible realm on the other hand. The former world is the world things-in-themselves, whereas the latter is world of the sensibility resulting from phenomena. Matter according to this framework, can be known as an object of experience through which we can only learn that it is force of attraction repulsion. Kant claimed that the matter is continuous quantity involving a proportion between the two fundamental forces of attraction and repulsion. The "idea" on which Kant based his investigation is "the idea of a transcendental philosophy", "which may serve for a critique of pure reason" ${ }^{2}$ and thus help determine the fate of future metaphysics. More precisely, it is the idea of a particular kind of self-examination or selfcognition, of reason.

Because metaphysics purports to be a priori knowledge of objects, the transcendental investigation must inquire into the possibility of such non-empirical reference to objects and must elucidate the conditions on which it depends. The concept of an "object in

\footnotetext{
${ }^{1}$ Kant (1965) §A1, §A13.

${ }^{2}$ Kant (1965) §A11.
} 
general" in Kant's definition of transcendental knowledge is consequently even wider in scope than the concept of logical possibility. Because we always directed the thought in its judgements toward something, it inevitably has an intentional object, "an object in general." The task for the transcendental inquiry is then to determine the conditions under which this concept of an "object in general" can become the concept of an object of our a priori knowledge. The Critique of Pure Reason thus establishes the criteria any metaphysics must meet to lay claim justifiably to knowledge of its objects.

To this end, metaphysics for Kant "isolates" the human cognitive faculties and examines their role in possible knowledge; it "abstracts from all objects that may be given" 3 and in this sense differs from all metaphysical knowledge. However, more crucial, the "idea of transcendental knowledge" also "serves for a critique of pure reason" and yields the plan on which such a critique is grounded. According to Kant, we have three types of concepts that refer a priori to objects: the concepts of space and time as forms of our sensibility, ${ }^{4}$ the categories of the understanding, ${ }^{5}$ and the ideas of reason. ${ }^{6}$

Kant also knew that the plan on which he grounded his investigation into possibility of metaphysics would be dark and obscure to the unprepared reader. Therefore, he decided to write another book in which he presented his results more explicitly. The result of his decision was Prolegomena to Any Future Metaphysics That Will Be Able to Come Forward as Science (1977). In its preface, Kant wrote that he offered in this book a plan which is sketched out after an analytical method, while the Critique itself had to be executed in the synthetical style, in order that the science may present all its articulations, as the structure of a peculiar cognitive faculty in their natural combination. ${ }^{7}$

Accordingly, in the Prolegomena Kant adopts a different procedure. In order to answer the question of "whether such a thing as metaphysics at all possible," he starts out the synthetic a priori propositions of mathematics and the natural sciences. He then asks how these propositions are possible, in order to from the principle that make them possible the possibility of all other a priori propositions. ${ }^{8}$ Because the propositions of metaphysics are synthetic and a priori, we must, Kant argues, elucidate the conditions of the possibility of metaphysics in the course of this "analytic" procedure, just as they were in the course of the first Critique. In the Prolegomena, however, the rational sciences of the objects of experience (mathematics and physics) provide the criterion any science of non-empirical objects (metaphysics) have to meet. Metaphysics proper is the science of the super-sensible and thus is concerned with objects that lie beyond all boundaries

\footnotetext{
${ }^{3}$ Kant (1965) §A845.

${ }^{4}$ Kant (1965) §A85.

${ }^{5}$ Kant (1965) §A85.

${ }^{6}$ Kant (1965) §A338.

${ }^{7}$ Kant (1977) 263.

8 See Kant (1977) 275.
} 
of experience. Rational physics, the philosophy of corporeal nature, can no longer be a part of the metaphysical system, to which the first Critique had assigned it. ${ }^{9}$ We have to treat it separately and as independent of the system of general metaphysics-a task Kant carried out in The Metaphysical Foundations of Natural Science.

In Opus Postumum, apart from all his efforts concerning the relations between the phenomena namely the knowledge of objects lying outside there, and the noumena namely the existence of things lying outside, beyond phenomena, Kant intends to construct a system in which the self will no longer need a combination of these two realms. ${ }^{10}$

\section{Opus Postumum}

In the manuscripts which we called Opus Postumum (originally around 1796-1803) Kant attempts to compose a work to be entitled Transition from The Metaphysical Foundations of Natural Science to Physics. Because Kant never finished this work, the scholars of Kant ${ }^{11}$ have to analyze these fragments with some unavoidable speculations. Though the fragmentary structure of the work makes it to difficult read, it still gives invaluable clues how Kant sees natural science in his old age. In the Preface to the Metaphysical Foundations of 1786, Kant explicitly argues that all philosophy may be done as the "pure doctrine of nature" so that we can get a complete a priori foundation of natural science. Thus, in this Preface, Kant compares his philosophical project with both pure mathematics and empirical science:

The reason for this is that in metaphysics the object is considered merely as it must be represented in accordance with the universal laws of thought, while in other sciences, as it must be in accordance with data of intuition (pure as well as empirical). Hence the former, inasmuch as the object must always be compared with all the necessary laws of thought, must furnish a definite number of cognitions, which can be fully exhausted; but the latter, inasmuch as such sciences offer an infinite manifold of intuitions (pure or empirical), and therefore of objects of thought, can never attain absolute completeness but can be extended to infinity, as in pure mathematics and the empirical doctrine of nature. ${ }^{12}$

But, in the Opus of 1796-1803, Kant is convinced that a new a priori science, the Transition, must be added to The Metaphysical Foundations. He claims, moreover, that without this new philosophical addition the "pure doctrine of nature" remains incomplete.

\footnotetext{
${ }^{9}$ I. Kant, for instance, writes "The whole system of metaphysics thus consists of four main parts: (1) ontology; (2) rational physiology; (3) rational cosmology; (4) rational theology. The second part, namely, the doctrine of nature as developed by pure reason, contains two divisions physica rationalis and psychologia rationalis." in the Critique of Pure Reason. See Kant (1965) §A846-847.

${ }^{10}$ See for example, I. Kant, (1993) 21:477.

${ }^{11}$ See for example, M. Friedman (1992).

${ }^{12}$ Kant (1985) 473.19-31.
} 
$<\mathrm{NB}$. Doctrine of nature and in general in the system from a priori principles - and thus towards accomplishing completely my metaphysical task $>13$;

through the latter [the Transition] a gap in the system pure natural science (philosophia naturalis pura) is now filled and the circle of all that belongs to a priori cognition is closed. ${ }^{14}$

As these passages suggest Kant's problem is not a simple fault between the natural science and the philosophy of nature, but the problem is closely relates his critical philosophy as a whole.

A comparison of the contents of The Metaphysical Foundations with those of the Transition, will show a striking separation in the scientific problems constituting the primary focus of philosophical research. The Metaphysical Foundations focuses on fundamental questions concerning space, time, and motion-and, accordingly, concentrates on rational mechanics and the application thereof to impact and the theory of universal gravitation. We therefore think about "a priori comprehensible universal characteristics of matter" such as impenetrability and weight. That is, only strictly universal properties of matter belong to metaphysics:

\begin{abstract}
Therefore, this elasticity and the aforementioned weight constitute the only a priori comprehensible universal characteristics of matter, the former being internal, the latter involving an external relation; for the possibility of matter itself rests upon two foundations. When cohesion is explained as the reciprocal attraction of matter insofar as this attraction is limited solely to the condition of contact, then such cohesion does not belong to the possibility of matter in general and cannot therefore be cognised a priori as bound up with matter. This property would hence not be metaphysical but physical, and therefore would not belong to our present considerations. ${ }^{15}$
\end{abstract}

The fundamental separation from the Metaphysical Foundations here can be expressed as follows: In the Transition project, the physics is not acknowledged for philosophy as the sole source for a priori foundation, and Kant includes chemistry as well. ${ }^{16}$ In the Metaphysical Foundations itself, on the other hand, chemistry is clearly not a part of the natural science. Kant, for example in The Metaphysical Foundations of Natural Science on $\S 468$ argues:

Only that whose certainty is apodeictic can be called science proper; cognition that can contain merely empirical certainty is only improperly called science. That whole of cognition which is systematic can therefore be called science, and when the

\footnotetext{
${ }^{13}$ Kant (1993) 626.7-11.

${ }^{14}$ Kant (1993) 640.4-6.

${ }^{15}$ Kant (1985) 518.

16 See, for example, I. Kant, Opus Postumum, 316.20-22, 288.5-6.
} 
connection of cognition in this system is a coherence of grounds and consequents, rational science. But when these grounds or principles are ultimately merely empirical, as, for example, in chemistry, and when the laws from which reason explains the given facts are merely laws of experience, then they carry with themselves no consciousness of their necessity (are not apodeictically certain), and thus the whole does not in a strict sense deserve the name of science. Therefore, chemistry should be called systematic art rather than science.

In the middle of the Dialectic, Kant presents us with a new synthetic a priori principle. This principle is a thoroughgoing determination of all things. According to Kant we come to know an object by determining it, that is, by ascribing predicates to it. ${ }^{17}$ The object is simply the bearer of certain predicates, a "something in general" that we think to ourselves through the predicates that constitute its concept. In principle, however, the object must also be determinable with respect to the predicates that we did not asserted or denied of it. The determinateness of the object precludes the possibility that any predicate may, at the same time, apply and not apply to it. Or, as Kant says,

But everything, as regards its possibility, is likewise subject to the principle of complete determination, according to which if all the possible predicates of things be taken together with their contradictory opposites, then one of each pair of contradictory opposites must belong to it. ${ }^{18}$

This principle depends on what Kant calls a necessary "transcendental presupposition," namely, the idea of a "transcendental substrate" that contains, as it were, "the whole store of material" for all possible predicates of things. We cannot think of a finite thing except in terms of some boundaries:

All manifoldness of things is only a correspondingly varied mode of limiting the concept of the highest reality which forms their common substratum, just as all figures are only possible as so many different modes of limiting infinite space. ${ }^{19}$

Thus, reason leads us to form the idea of an object that, although we regard transcendent as being thoroughly determinable in accordance with principles. In other words, we form an ideal, by which Kant understands an idea, "not merely in concreto, but in individuo, that is as an individual thing, ${ }^{\prime 20}$ determined or determinable by the idea alone.

\footnotetext{
${ }^{17}$ I. Kant, New Elucidation, proposition IV, 1:391. Cf. Critique of Pure Reason §A598/B626.

${ }^{18}$ Kant (1965) §A571-572/B599-600.

${ }^{19}$ Kant (1965) §A578/B606.

${ }^{20}$ Kant (1965) §A568/B569.
} 


\section{Conclusion}

The conclusion of the Aesthetic of the first Critique is that we cannot conceive of objects without conceiving them as spatial or temporal. In the Analytic, Kant shows that there can be no object without the activity of the understanding: Kant endeavors to show it is impossible that a concept although itself neither contained in the concept of a possible experience nor consisting of elements of a possible experience should be produced completely a priori. [A95] He saw it as the task of transcendental methods to comprehend those fundamental facts by which a person proves himself or herself to be endowed with reason. To be conscious is to be conscious of an object. In other words, consciousness is intentional. But it is also to have synthesized the given representations under the concept of an object. In the very same act, it is also to judge.

Thus, Kant insists that consciousness therefore is synthesis. He believes that if we have an intuitive representation, this does not involve consciousness until such representation is brought under the unity of a concept, that is, of an objective judgment. Kant asks: What is assumed or presupposed whenever a content is posited as object of experience - as object for a subject? The objection he makes to philosophers like Descartes and Berkeley is that they doubt and deny, respectively, the existence of objects in space, while continuing to affirm their own existence. The counter argument says that to know our own existence as determined in time we must know objects in space. Kant believes that Transcendental idealism implies empirical realism. If you say that all objects of experience are transcendentally ideal, you are saying that we can directly perceive both material and mental objects in our experience. This is so because both material and mental objects are just objects of possible experience. This supposedly follows from the claim that space and time are forms of our intuition and not properties of things independently of possible experience.

Kant does not deal with the faculties of the mind but with functions which must be fulfilled if experience is to be possible. There is a sense in which Kant's transcendental reflection does not serve knowledge as such but rather grasping. What are grasped are the conditions of knowledge. These are grasped when their totality can be thought, that is to say, when a concept of the unconditioned is thought as the ground of all conditions. The significance of Kant's transcendental philosophy is two-fold. It is entirely devoid of any empirical content, whether of sensory objects or of mental faculties. Secondly, it is entirely concrete both in its intentions and its achievements. Kant is insistent that the formal aspects of experience are useless without the content provided in sensory intuition and however far our knowledge may be extended using speculative reason, we can never go beyond the limits of possible experience. Therefore, our transcendental horizon is always within the limits of possible experience.

The fundamental question that Kant sets out to answer in his Critique of Pure Reason is, What is it to think at all? What operations of the understanding are required for thinking in general and how are we thinking of anything that can be thought about? 
The first Critique is not primarily concerned with the object of theoretical knowledge as such, but rather with the a priori principles on the one hand and the objects of knowledge on the other. The question Kant seeks to answer is: How is such a relation possible and upon what is it to be found? The philosophical investigation which tries to reveal the inner connection between the pure concepts of reason (the categories and the principles) by determining them to be related a priori to objects constitutes transcendental philosophy. Therefore, human knowledge comes about by an interaction of objective structures (the cognitive apparatus). It is in the light of this that Kant can say:

All principles of the pure understanding are nothing more than principles a priori of the possibility of experience, and to experience alone do all a priori synthetic propositions relate - indeed, their possibility itself rests entirely on this relation. [B294]

Thus, the question concerning the condition of the possibility of synthetic judgments a priori is the famous transcendental question.

Kant self-consciously refers to his new approach to philosophical method as a Copernican Revolution. He draws references to the fact that just as Copernicus radically changed the human perception of the movement of heavenly bodies, he intends to reverse the traditional understanding of the knowing process by uncovering the principles that can be known a priori in the realm of knowledge. To accomplish this, he starts out by suggesting that whereas philosophers had always insisted that human knowledge must always conform to the objects of knowledge, we might better be able to account for what is involved in the knowing process if we begin with the premise that objects must conform to the human capacity of knowing. This move by Kant was indeed epoch-making and revolutionary. It signifies a re-orientation in man's view of himself.

Geometric propositions cannot constitute an analysis of our concept of space, for they would be analytic a priori. By a process of elimination, they must therefore be explained not by our concepts but by our intuitions, that is to say, by our acquaintance with particulars. But empirical intuitions would not be able to explain how any propositions could be a priori. So only an a priori intuition can explain the possibility of geometry. But the only a priori acquaintance with particulars that we have is our knowledge of space and time. For these are not given to us but are the forms under which we perceive all other particulars. Because Kant thinks that a priori knowledge is possible only when our knowledge determines its object rather than the other way around.

Human knowledge is limited to space and time. Kant believes that all our representations must be in space or time. Since the unity of space and time presupposes a synthesis which does not belong to the senses but to the understanding and its categories, Kant further argues that everything that is to be known as determined in space or in time must conform to the categories. 
Kant argues that not only the unity of consciousness but also the universality and the unity of space and time are necessary to guarantee the universal validity of the categories. Thus, we can know objects which correspond to the representation given to us through space and time and the objectivity of these objects is possible only by the categories.

Numerous philosophers have interpreted Kant's critical philosophy in different ways. Some have suggested that for Kant reality is supersensible and unknowable, and all that is available to human consciousness is mere appearance. Others have argued that Kant postulated two distinct realms or entities, the realm of things in themselves and that of appearances. Thus, the proponents of the two-world theory argue that there is a fundamental dichotomy or contradiction in Kant's transcendental philosophy.

However, I have shown that there is no contradiction in Kant's critical philosophy. On the contrary I am convinced that the philosophical method introduced by Kant is the one that does the greatest justice to what is involved in the knowing process. It is generally agreed that we do not have one to one correspondence with the object of experience. Knowledge of object is always mediated. There are certain constraints placed on human reason based on the fact of human finitude.

Human beings are limited to space and time. The only way that an object can be given is through space and time. For space and time are not the properties of things given in sensory experience but are the forms under which we perceive all objects of experience. Whatever ability there is for the human person to comprehend any object of possible experience must be within the a priori forms of space and time. Thus, space and time are empirically real and transcendentally ideal. There is an empirical side and a transcendental side to human consciousness.

To know our own existence as determined in time we must know objects in space. What is more, whatsoever appears on the horizon of human consciousness (both the mental and the physical) are phenomena for transcendental philosophical reflection. In critical philosophy, we are dealing with both the empirical subject as experiencing and the empirical subject as experience and both form a unity. Thus, transcendental reflection reveals that there is a unity to human experience. The distinction between the subject and the object takes place in the activity of reason exercising its transcendental function.

I believe that Kant's critical philosophy is fully concrete to the extent that he has clearly demonstrated that inner experience is possible only on the assumption of outer experience. In Opus Postumum, Kant despite all his efforts, fails to provide completed answer for the Transition problem, but some scientific developments in his time urge him to re-think his definition of a prioricity and to include chemistry as model science for philosophy. 


\section{REFERENCES}

Friedman, M. (1992). Kant and the Exact Sciences. Cambridge, Mass.: Harvard University Press.

Kant, I. (1965). Immanuel Kant's Critique of Pure Reason (N. K. Smith, Trans.). New York: St Martin's Press.

Kant, I. (1977). Prolegomena to Any Future Metaphysics That Will Be Able to Come Forward as Science ( P. Carus, Trans.). Indianapolis: Hackett Publishing Co.

Kant, I. (1929). Kant's Inaugural Dissertation and Early Writings on Space (J. Handyside, Trans.). Chicago: Open Court Pub. Co. (Republished Connecticut: Hyperion Press, 1979).

Kant, I. (1985). The Metaphysical Foundations of Natural Science in Philosophy of Material Nature (J. W. Ellington, Trans.). Indianapolis: Hackett Publishing Co.

Kant, I (1993). Opus Postumum (E. Förster \& M. Rosen, Trans.). New York: Cambridge University Press. 